кандидат педагогічних наук, доцент (Національна академія Державної прикордонної служби імені Богдана Хмельницького) berestetskanat@ukr.net

ORCID : $0 \odot \odot \odot-\odot \odot \odot 2-3047-3015$

\title{
ІНТЕРАКТИВНІ ТЕХНОЛОГІЇ ПІД ЧАС ПОЗААУДИТОРНОЇ САМОСТІЙНОЇ РОБОТИ МАЙБУТНІХ ПРИКОРДОННИКІВ У ВІДОМЧИХ НАВЧАЛЬНИХ ЗАКЛАДАХ РЕСПУБЛІКИ ІНДІЯ
}

У статті представлено аналіз інтерактивних технологій, які використовуються під час позааудиторної самостійної роботи майбутніх прикордонників у відомчих навчальних закладах Республіки Індія, а саме: мозаӥчне навчання, проектування, "парне програмування", "перевернутий клас", горизонтальне навчання, ігрові вправи, "навчальна секція" та навчальні візити. 3 'ясовано особливості імплементації інтерактивних технологій під час позааудиторної самостійної роботи майбутніх прикордонників в індійських відомчих навчальних закладах, а також обтрунтовано їхні переваги в системі професійної підготовки прикордонників у Республіџі Індія.

Ключові слова: професійна підготовка, інтерактивні технології, проекти, "парне програмування", "перевернутий клас", горизонтальне навчання.

Постановка проблеми. Мета професійної підготовки кожного фахівця, у тому числі майбутніх прикордонників, полягає не лише у засвоєнні знань, вмінь та навичок під час вивчення курсу, а й у подальшому інтелектуальному розвитку персоналу, бажанні та вмінні самостійно засвоювати нову інформацію, опановувати нові навички, вміти працювати в групі та виконувати функцію лідера, самостійно приймати рішення, тощо, що буде необхідним у процесі професійної діяльності. Наявність готовності у майбутніх прикордонників до самостійної роботи є гарантією підтримання та підвищення їх кваліфікації в системі неперервної професійної підготовки під час служби в органах охорони кордону та, в свою чергу, якісного виконання професійних обов'язків, незважаючи на зміну завдань та загроз. Крім того, важливість самостійної роботи майбутніх прикордонників зростає у зв'язку з необхідністю отримання широкої фундаментальної підготовки 3 одного боку та інтенсивністю підготовки й іiі мінливістю відповідно до завдань, які постають перед прикордонним відомством.

Аналіз основних досліджень i публікацій. Проблемам самостійної роботи майбутніх військовослужбовців в Україні та закордоном приділяли увагу багато вітчизняних дослідників (О. Торічний, О. Діденко, І. Блощинський, С. Білявець, В. Веретільник, В. Кравчук, О. Лазоренко, I. Маріонда, А. Мірошниченко, Ю. Мойсєєнко, А. Чудик, І. Яремчук та ін.), проте аналіз індійської системи професійної підготовки фахівців сектору безпеки незаслужено лишається поза увагою вітчизняних вчених. Серед індійських дослідників варто назвати таких: Р. Кумар, А. Суятха Деві, К. Венката Редді, С. Куппусвамі, К. Вівеканандан, Н. Сандху, Д. Сінгх, С. Шарма, К. Срівастава, А. Кхарат, Р. Джоші, А. Бададхе, С. Джеюрікар, Т. Кулшрестха, К. Нагпал, Пріямакхія, Гйянпракаш, Б. Пама, К. Саіні та ін. Крім того, варто відмітити, що події в Україні 2014 - 2015 рр., а також питання підготовки військовослужбовців були предметом досліджень окремих індійських вчених та військових експертів (Дж. Аггарвал, Т. Гуай, М. Мукхерджі, Р. Шарма, Р. Сукма, К. Натхан та ін.). Зважаючи на наявність схожості безпекових загроз у галузі охорони кордону, низки соціально-політичних особливостей розвитку обох країн, а також враховуючи роль прикордонних відомств для забезпечення гармонійного розвитку державності, питання підвищення готовності прикордонників до виконання службових завдань $є$ важливим завданням і в Україні, і в Республіці Індія. Тому вважаємо необхідним детально проаналізувати досвід Республіки Індія у галузі професійної підготовки прикордонників 3 можливою творчою імплементацією окремих ідей для підготовки персоналу Державної прикордонної служби України.

Мета статті - проаналізувати особливості застосовування інтерактивних технологій під час групової самостійної роботи майбутніх фахівців прикордонних відомств Республіки Індія.

Виклад основного матеріалу. Суспільні зміни впливають на важливість професійної підготовки фахівців усіх галузей, у тому числі прикордонників, що, у свою чергу, вимагає використання нових методів навчання для підвищення рівня готовності тих, хто навчається. Вимогою таких методів $\epsilon$ перенесення акцентів з викладача на того, хто навчається, оскільки тільки активна діяльність слухачів забезпечує якісний процес отримання знань, вмінь та навичок, а також застосування їх у майбутньому. Тому ми беззаперечно погоджуємося з К. Венката Редді, який стверджує, що для якісної професійної підготовки процес навчання повинен включати, окрім комунікації у форматі "викладач - слухач", роботу у форматі "слухач - слухач(i))", [1], що означає широке використання інтерактивних технологій. Так, інтерактивне навчання - альтернатива традиційним методам навчання. Р. Кумар зазначає, що, коли 
слухачі активно залучені до роботи під час виконання завдань, вони більше вивчають у порівнянні 3 пасивною поведінкою [2].

Оскільки інтерактивне навчання стосується використання прийомів розумової діяльності, а не лише пам'яті, то для тих, хто навчається, це процес відкриття, під час якого слухач - головний учасник, а не викладач. Слухачі найкраще вчаться тоді, коли їх залучають до мислительної діяльності, коли вони виконують живі практичні вправи, беруть участь у процесах отримання нової інформації, здійснюють дослідження та інтерпретації. Якісь навчання підвищується за умови, якщо слухачі повторюють інформацію своїми словами, наводять власні приклади чи використовують дані, які отримали від викладача, а також впливають на хід діяльності. I навпаки, якщо слухачі пасивні, вони не виконують мислительні операції ефективно і не засвоюють якісно інформацію.

Р. Кумар підтримує думку Л. Виготського та М. Вільямса і стверджує, що існує "зона найближчого розвитку", що означає, що слухачі не можуть вдосконалити вміння та навички, якщо вони працюють 3 викладачем, а саме: вони знають алгоритм виконання завдання, який пропонує викладач, знають, що від них вимагає викладач, тому не зможуть виконувати його на професійному рівні спонтанно при зміні окремих елементів [2; 3]. Вдосконалити навички можна безпосередньо під час професійної діяльності (на місцях служби), що неможливо під час навчання у відомчому навчальному закладі, або ж у класі під час виконання інтерактивних вправ - коли курсанти будуть працювати самостійно. Крім того, використання інтерактивних технологій підвищує емоційний розвиток, уяву та дозволяє тим, хто навчається, експериментувати з різними даними та джерелами [4].

У той же час самостійна робота - важлива частина професійної підготовки майбутніх фахівців прикордонних відомств у Республіці Індія. Її поширення обумовлене певними особливостями навчального процесу в індійських відомчих навчальних закладах, а саме [5; 6; 7]: 1) велика кількість курсантів у відомчих навчальних закладах; 2) нестача науково-педагогічних кадрів та інструкторів для проведення аудиторних занять; 3) можливість застосування технічних засобів для імплементації дистанційного навчання; 4) необхідність виконувати службові обов'язки курсантами (бойове чергування, нічні тренування, тощо), брати участь у національних та міжнародних спортивних змаганнях та ін.; 5) необхідність гнучкості робочого часу викладачів та інструкторів (участь в роботі конференція, стажування, у тому числі закордоном, проведення лекцій в інших навчальних закладах та участь в роботі національних комісій з питань освіти та ін.).

Крім того, нові вимоги до майбутніх фахівців вимагають формування у них нових вмінь та навичок, поряд із фундаментальними знаннями, які $є$ актуальними й для майбутніх прикордонників 3 окремих дисциплін [7]. Вони є такими: 1) вміння працювати самостійно і в групі для досягнення якісних наукових результатів; 2) лідерські навички, вміння правильно сформулювати інструкції для підлеглих; 3) вміння налагоджувати ефективне міжособистісне спілкування з представниками різних груп; 4) вміння швидко та правильно приймати рішення; 5) самоконтроль, самодисципліна та взаємоконтроль; 6) мотивація до майбутньої професійної діяльності та саморозвитку. На нашу думку, формування перелічених вмінь та навичок відбувається краще під час застосування саме інтерактивних технологій, у тому числі і під час позааудиторної самостійної роботи.

У зв'язку з цим, на основі аналізу наукової літератури $[4 ; 5 ; 6 ; 7]$, ми можемо зробити висновок, що у відомчих навчальних закладах Республіки Індія поширеними $є$ групові форми позааудиторної самостійної роботи, серед яких можна назвати наступні: мозаїчне навчання, проектування, "парне програмування", "перевернутий клас", горизонтальне навчання, ігрові вправи, "навчальна секція" та навчальні візити курсантів в інші навчальні заклади чи органи охорони державного кордону (Рис. 1). Проаналізуємо їх детальніше.

Мозаїчне навчання означає самостійне опрацювання окремої частини навчального матеріалу в групі, тобто слухачі об’єднуються в групи, а увесь навчальний матеріал викладач ділить на рівноцінні частини. Кожна група під час позааудиторної самостійної роботи вивчає свою частину, а після цього презентує ії для всієї групи під час аудиторного завдання. Таким чином, в результаті вся група отримує завершену "мозаїку" [1]. Для підвищення ефективності такої вправи рекомендовано використовувати один комплект навчальних матеріалів (підручник, тощо) для однієї групи слухачів, що називається "стратегія одного підручника" (one-book referral strategy). Р. Кумар вважає, що так їм доведеться працювати разом, а не індивідуально [2]. 


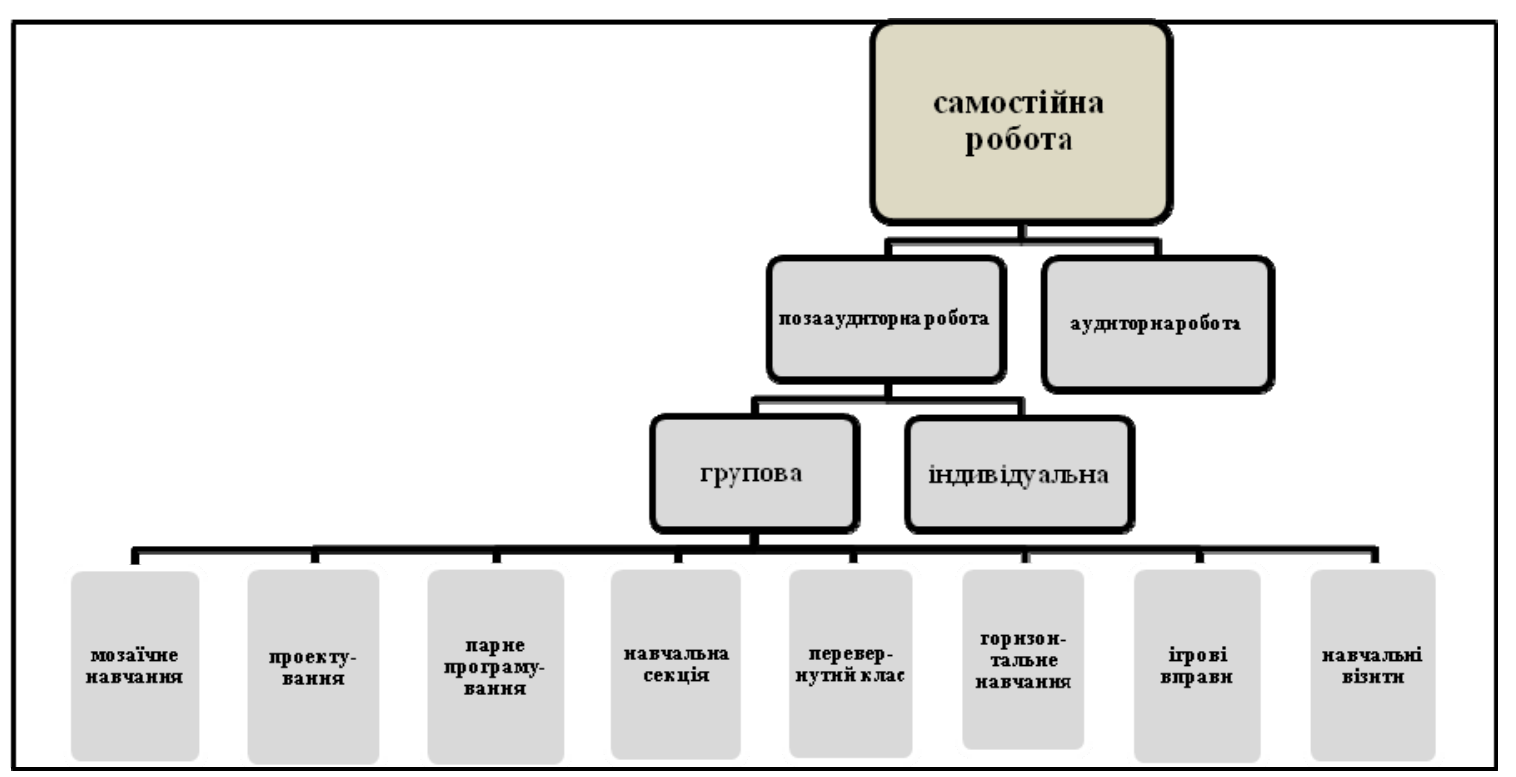

Рис. 1. Інтерактивні технологї̈ під час позааудиторної самостійної роботи майбутніх прикордонників

"Навчальна секція" - спільне навчання в парах [7]. Під час виконання цієї вправи два слухачі ставлять запитання з визначеної теми чи щодо матеріалів, які прочитали один одному та відповідають на них. Варто зазначити, що вони по черзі змінюють ролі. Готуючись до вправи, слухачі читають матеріал та записують запитання, які будуть ставити іншому учаснику. Під час аудиторного заняття одна 3 секцій, за власним бажанням чи вибором викладача, презентують вивчений матеріал.

Проектування означає здійснення власного наукового дослідження чи осмислення самостійно отриманої інформації, рішення науково-технічних задач, розробки конкретних проектів у групі. Основою такої діяльності є творчість. Знання, вміння, навички в такій системі розглядаються не як ціль навчання, а як засіб розвитку того, хто навчається, формування його методологічного стилю мислення, підготовка до професійного функціонування та життєдіяльності в умовах технологічного суспільства. Ця ціль реалізується за допомогою розвитку здібностей та набуттям практичного досвіду, споглядальної професійної творчої діяльності, виховання особистої відповідальності за створені та імплементовані реальні проекти під час навчальних та професійно-тренувальних ситуацій [6]. Проектування суттєво змінює процес навчання, адже знання уже не представлені в готовій формі, а їх потрібно отримати самостійно. Особлива увага приділяється в такій діяльності приділяється розвитку вмінь вирішувати різноманітні практичні задачі та проблемні ситуації.

"Парне програмування" означає спільну роботу двох осіб за одним комп’ютером під час дизайну, кодування та тестування комп'ютерних програм. Два слухачі мають окремі ролі - машиніста та навігатора, оскільки машиніст пише код, а навігатор допомагає йому та перевіряє помилки. Кожен 3 учасників парного програмування вносить свій досвід, знання, бачення перспективи, проникливість, інтуїцію, вміння, навички та установи, що допомагає підвищити результати навчання для обох слухачів [8]. С. Куппусвамі та К. Вівеканандан стверджують, що переважно під час виконання завдань, які стосуються комп'ютерного програмування, слухачі ділять між собою роботу і працюють індивідуально. Обов'язковою умовою "парного програмування" $є$ те, щоб слухачі обоє сиділи за одним терміналом та разом виконували усі дії разом [8]. Такі вправи належать до довготривалих завдань та виконуються під час самостійної роботи слухачів, а не під час аудиторних завдань.

"Перевернутий клас" - двостороння чи багатостороння взаємодія слухачів під час самостійного отримання знань Під час імплементації "перевернутого класу" слухачі без допомоги викладача опрацьовують наукові джерела, електронні носії, мультимедійні презентації, асоціативні карти, відеолекції, фільми та анімація, масові відкриті онлайн-курси, звичайні підручники чи покликання на додаткові веб-ресурси з визначної теми, виконують тестові завдання та практичні вправи, тощо для підготовки перед аудиторним заняттям. Крім того, слухачі оцінюють один одного.

Під час лекції слухачі з викладачем обговорюють незрозумілі питання, які в них виникли під час самоопрацювання матеріалів. К. Срівастава наголошує на збільшення ролі "перевернутого класу" в зв'язку з об'єктивним ростом теоретичного матеріалу та нестачею аудиторних годин для їх вивчення, а також з появою нових технічних засобів та технологій у процесі професійної підготовки, які дозволяють оптимально використовувати навчальний час [9] для синтезу та аналізу матеріалу, практиці застосуванню знань, виконання вправ на закріплення. "Перевернутий клас" дозволяє слухачам регулювати швидкість, з якою вони навчаються, власне час, коли вони можуть працювати та формат 
роботи (читання про себе чи вголос, ведення нотаток, обговорення в парах чи у великих групах, тощо). Матеріали, які отримують слухачі для роботи повинні бути спеціально розроблені для використання поза класом, щоб уникнути неправильного трактування термінів чи помилкового розуміння деяких аспектів теми.

Окремим видом інтерактивних технологій є ігри. Гра - це вид навчальної діяльності, яке відбувається в штучно створених умовах, які наближені до професійної ситуації і орієнтована на засвоєння та вдосконалення знань, вмінь та навичок [4]. На сьогодні спостерігається поширення ігор у процесі професійної підготовки військовослужбовців, у тому числі прикордонників, зокрема під час позааудиторної самостійної роботи, а саме ігрові вправи (кросворди, ребуси, ігрові тести, загадки, тощо, у тому числі 3 використанням комп'ютерних технологій). Застосування ігрових вправ сприяє закріпленню знань, формуванню нових вмінь та навичок, допомагає зрозуміти проблему та прийняти правильне рішення, розвиває навички спілкування, менеджменту та лідерства, сприяє вдосконаленню навичок роботи в команді, допомагає зрозуміти та передбачити поведінку інших [4].

Горизонтальне навчання - двостороннє взаємне навчання, що передбачає обмін знаннями, ідеями, навичками між тими, хто навчається. На думку С. Гріффітс, К. Хьюстона та А. Лазенбатта є десять моделей горизонтального навчання [10], які активно використовуються у процесі професійної підготовки фахівців: прокторна модель горизонтального навчання, коли слухач старших курсів виконує роль консультанта, дискусійні семінари, закриті дискусійні групи, "група друзів" (buddy group), консультація, схема горизонтального оцінювання, спільне навчання, лабораторна робота, наставництво, спільна суспільна діяльність (підготовка та участь в акціях, тематичних флешмобах, тощо).

Навчальні візити у складі групи в інші навчальні заклади чи органи охорони державного кордону 3 метою отримання нових професійних знань, вмінь та навичок, під час яких курсанти працюють за попередньо складеним планом керівником навчального візиту та виконують визначені завдання [5] (ознайомлення $з$ особливостями застосування зброї та спеціальної техніки, аналіз відвіданих занять, підготовка презентацій, тощо).

На основі аналізу наукової літератури $[1 ; 2 ; 4 ; 7 ; 8 ; 9 ; 10]$ ми можемо зобразити модель імплементації інтерактивних технологій під час позааудиторної самостійної роботи майбутніх прикордонників в індійських відомчих навчальних закладах, що включає 5 етапів: 1) інструктування курсантів перед початком поза аудиторної самостійної роботи; 2) інтерактивне навчання курсантів з урахуванням їхніх індивідуальних особливостей; 3) етап засвоєння матеріалу, а при необхідності повторення у парах чи малих групах; 4) контроль засвоєння навчального матеріалу під час аудиторних занять; 5) досягнення мети - формування професійних знань, вмінь та навичок (Рис. 2).

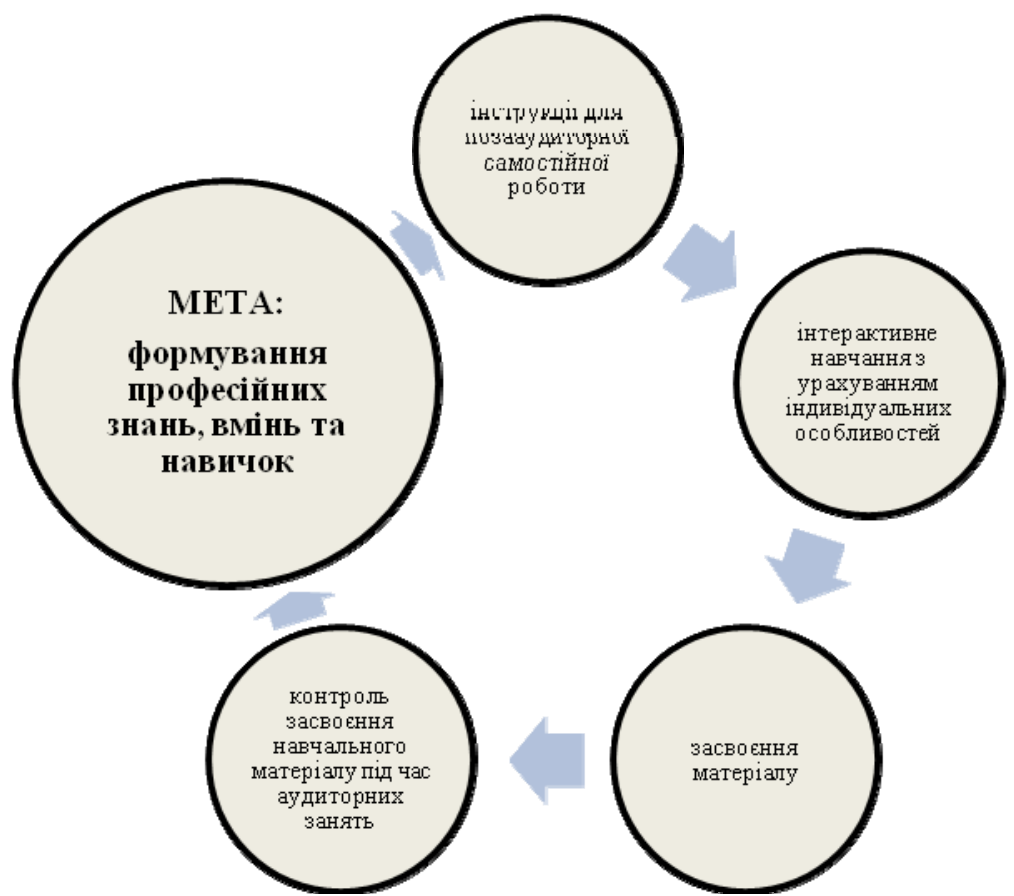

Рис. 2. Імплементація інтерактивних технологій під час позааудиторної самостійної роботи майбутніх прикордонників в індійських відомчих навчальних закладах 
Таким чином, ми можемо зробити висновок, що використання інтерактивних технологій під час позааудиторної самостійної роботи майбутніх прикордонників у відомчих навчальних закладах Республіки Індія має низку переваг:

1) Зручність для тих, хто навчається (курсанти можуть дивитися відеозапис лекції чи працювати 3 підручниками, коли їм зручно і вибираючи оптимальну для себе швидкість; існує можливість робити перерви під час роботи за згодою усіх учасників групи; можливість отримувати знання для курсантів, які пропускають аудиторні заняття через змагання, відрядження, тощо.

2) Розширене навчання (можливість вивчити додатковий матеріал з теми; навчання відбувається поза навчальним класом, а під час аудиторного заняття курсанти закріплюють матеріал).

3) Ефективний зворотній зв'язок (зменшення кількості помилок через зворотного зв'язку).

4) Високий рівень двосторонньої взаємодії (курсанти виконують завдання у парах чи малих групах).

5) Можливість повторення вивченого матеріалу.

6) Оптимальне використання аудиторного часу, особливо це стосується випадків, коли лекції проводить запрошений лектор.

7) Формування індивідуальних психологічних характеристик, які необхідні для майбутнього фахівця прикордонного відомства (лідерство, відповідальність, самоконтроль, дисциплінованість, мотивація, робота в команді, тощо).

Проте, на нашу думку, для успішного використання позааудиторної самостійної роботи у процесі професійної підготовки прикордонників слід врахувати наступні вимоги, а саме:

1) Оскільки одним із головних аргументів для імплементації позааудиторної самостійної роботи у процесі професійної підготовки прикордонників є те, що час, який виділяється на взаємодію курсанта та викладача, є дуже цінним, і його не потрібно витрачати на вправи (перегляд відео, читання підручників, тощо), які ті, хто навчається, можуть успішно виконати й самостійно. Проте існує загроза неправильного тлумачення окремих аспектів. Таку проблему викладач повинен передбачити і використовувати лише матеріали, які спеціально розроблені для цієї мети, де будуть перевірені усі терміни і де не може бути двоякого трактування.

2) Рекомендовано не застосовувати такий підхід під час початкового етапу вивчення дисципліни чи теми, а приблизно з третього курсу, коли курсанти мають достатній рівень професійних знань, вмінь та навичок і можуть обмінюватися власним досвідом та контролювати один одного під час виконання вправ у групах.

3) Курсанти повинні мати повний доступ до матеріалів (як друковані, так і електронні).

4) Курсанти повинні приходити на лекцію добре підготовленими, опрацювавши повний обсяг матеріалу, який виділявся на самостійну підготовку. Бажано, що усі курсанти знали матеріал. Якщо трапляється випадок невиконання завдань для позааудиторної самостійної роботи, викладач повинен використовувати інші форми навчання та мотивації.

5) Необхідно використовувати різні інструменти для оцінювання рівня підготовки курсантів на початку лекції з метою ефективного застосування завдань під час аудиторної роботи.

6) Визнання позааудиторної самостійної роботи як невід’ємної частини програми підготовки науковопедагогічним складом та керівництвом відомчого навчального закладу, що допомагає курсантам ставитися до виконання завдань серйозно, у тому числі виділяти час під час дозвілля для роботи у групі.

7) Рекомендовано застосовувати технічні засоби навчання та елементи дистанційного навчання, а також програмне забезпечення для моніторингу діяльності курсантів.

8) Не рекомендовано використовувати такі завдання постійно.

Висновки та перспективи подальшого дослідження проблеми. Перелічені інтерактивні технології, які використовуються під час позааудиторної самостійно роботи курсантів відомчих навчальних закладів у Республіці Індія, а саме: мозаїчне навчання, проектування, "парне програмування", "перевернутий клас", горизонтальне навчання, ігрові вправи, "навчальна секція" та навчальні візити, дозволяють підвищити ефективність процесі професійної підготовки майбутніх фахівців прикордонних відомств, оптимально використовувати навчальний час, а також можливість формування індивідуальних психологічних характеристик, які необхідні для майбутнього прикордонника для ефективного виконання професійних завдань

У подальшому передбачається аналіз модернізації процесі підготовки персоналу Державної прикордонної служби України з урахуванням досвіду індійських прикордонних відомств.

\section{СПИСОК ВИКОРИСТАНИХ ДЖЕРЕЛ ТА ЛІТЕРАТУРИ}

1. Venkata Reddy K. Changing Attitudes To Education In India / K. Venkata Reddy. - New Delhi. Atlantic Publishers and Distributors, 2002. - $128 \mathrm{p}$.

2. Kumar R. D. Students' Classroom Participation for Improved Learning in an English Language Skills Course : An Action Research Report / R. D. Kumar. - Working Paper No. 21. - October 2007. - P. 1-8. - Режим доступу : http://www.crie.org.nz/research-papers/r.d.kumar_wp.pdf. 
3. William M. Vygotsky's Social Theory of Mind / M. William // Harvard Educational Review. - No 59 (1). February, 1989. - P. 108-126.

4. Sujatha Devi A. Active Learning Models for Effective Teaching / A. Sujatha Devi. - Hyderabad. UGC-Academic Staff College, Jawaharlal Nehru Technological University, 2014. - 19 p. - Режим доступу: http://jntuhhrdc.in/docs/Mini\%20project.pdf.

5. Pama B. Paradigm Shift in Training in the Army / B. Pama. - New Delhi. - KW Publishers Pvt. - Ltd, 2008. $260 \mathrm{p}$.

6. Saini S. K. Revamping the Military Training System / S. K. Saini. // Journal of Defence Studies. - Vol. 2. $\begin{array}{llllll}\text { Issue } 1 . & -2008 . & - & \text { P. 65-78. } & - & \text { Режим доступу: }\end{array}$ https://idsa.in/jds/2_1_2008_RevampingtheMilitaryTrainingSystem_SKSaini.

7. Nagpal K. Independent Learning and Student Development / K. Nagpal, Priyamakhija, L. James, Gyanprakash // International Journal of Social Science \& Interdisciplinary Research. - Vol. 2 (2). - February 2013. - P. $27-35$.

8. Kuppuswami S. The Effects of Pair Programming on Learning Efficiency in Short Programming Assignments / Kuppuswami S., Vivekanandan K. // Informatics in Education. - 2004. - Vol. 3. - No. 2. - P. 251-266.

9. Srivastava K. Role of Flipped Classroom in Education / K. Srivastava // PARIPEX - Indian Journal of Research / A. Kumar (ed.)]. - Vol. 3. - Issue 4. - April, 2014. - P. 81-83.

10. Griffiths S. Enhancing Student Learning Through Peer Tutoring in Higher Education / Griffiths S., Houston K., Lazenbatt A. - Coleraine. - University of Ulster, 1995. - 124 p.

\section{REFERENCES (TRANSLATED \& TRANSLITERATED)}

1. Venkata Reddy K. Changing Attitudes To Education In India / K. Venkata Reddy. - New Delhi. - Atlantic Publishers and Distributors, 2002. - 128 p.

2. Kumar R. D. Students' Classroom Participation for Improved Learning in an English Language Skills Course : An Action Research Report / R. D. Kumar. - Working Paper No. 21. - October 2007. - P. 1-8. - Режим доступу : http://www.crie.org.nz/research-papers/r.d.kumar_wp.pdf.

3. William M. Vygotsky's Social Theory of Mind / M. William // Harvard Educational Review. - No 59 (1). February, 1989. - P. 108-126.

4. Sujatha Devi A. Active Learning Models for Effective Teaching / A. Sujatha Devi. - Hyderabad. UGC-Academic Staff College, Jawaharlal Nehru Technological University, 2014. - 19 p. - Rezhym dostupu : http://jntuhhrdc.in/docs/Mini\%20project.pdf.

5. Pama B. Paradigm Shift in Training in the Army / B. Pama. - New Delhi. - KW Publishers Pvt. - Ltd, 2008. $260 \mathrm{p}$.

6. Saini S. K. Revamping the Military Training System / S. K. Saini. // Journal of Defence Studies. - Vol. 2. $\begin{array}{lllllll}\text { Issue } 1 . & - & 2008 . & - & \text { P. 65-78. } & - & \text { Rezhym }\end{array}$ https://idsa.in/jds/2_1_2008_RevampingtheMilitaryTrainingSystem_SKSaini.

7. Nagpal K. Independent Learning and Student Development / K. Nagpal, Priyamakhija, L. James, Gyanprakash // International Journal of Social Science \& Interdisciplinary Research. - Vol. 2 (2). - February 2013. - P. $27-35$.

8. Kuppuswami S. The Effects of Pair Programming on Learning Efficiency in Short Programming Assignments / Kuppuswami S., Vivekanandan K. // Informatics in Education. - 2004. - Vol. 3. - No. 2. - P. 251-266.

9. Srivastava K. Role of Flipped Classroom in Education / K. Srivastava // PARIPEX - Indian Journal of Research / A. Kumar (ed.)]. - Vol. 3. - Issue 4. - April, 2014. - P. 81-83.

10. Griffiths S. Enhancing Student Learning Through Peer Tutoring in Higher Education / Griffiths S., Houston K., Lazenbatt A. - Coleraine. - University of Ulster, 1995. - 124 p.

\section{Бхиндер Н. В. Интерактивные технологии во время внеаудиторной самостоятельной работы будущих пограничников в ведомственных учебных заведениях Республики Индия.}

В статье представлено анализ интерактивных технологий, которые используются по время внеаудиторной самостоятельной работы будущих пограничников в ведомственных учебных заведениях

Республики Индия, а именно: мозаичное обучение, проектирование, "парное программирование",

"перевернутый класс", горизонтальное обучение, игровые упражнения, "учебная секция" и учебные визиты. Выяснено особенности имплементации интерактивных технологий во время внеаудиторной самостоятельной работы будущих пограничников в индийских учебных заведениях, а также обосновано

их преимущества в системе профессиональной подготовки пограничников в Республике Индия.

Ключевые слова: профессиональная подготовка, интерактивные технологии, проектирование, "парное программирование", "перевернутый класс", горизонтальное обучение.

\section{Bkhinder N. V. Interactive Technologies during Extracurricular Self-Study Activities of Future Border Guards at the Agency-Specific Educational Establishments in the Republic India.}

The research deals with the analysis of interactive technologies used during extracurricular self-study activities of future border guards at the agency-specific educational establishments in the Republic of India. They are the following: mosaic learning, projects, "pair programming", "flipped classroom", peer learning, game-based exercises, "study cell" and study visits. The material of the research proves that considering peculiarities of 
Indian professional training some interactive technologies are efficient during extracurricular self-study activities. The scientific methods used were the following: archival research, content analysis, generalization of scientific material, deductive method of analysis. Also living in the Republic of India for a while the author used non-participant observation method.

The results obtained during the research concern the definition and peculiarities of interactive technologies as well as description of extracurricular self-study activities based on the works of Indian scientists. Also the author enumerated all interactive technologies used during extracurricular self-study activities at the agencyspecific educational establishments in the Republic of India and specified them. The main attention was drawn towards the advantages of usage of interactive technologies used during extracurricular self-study activities at

the agency-specific educational establishments in the Republic of India as they are defined to be proven instruments of formation of future leaders.

The conclusion made is the following: it is necessary to investigate the process of professional training of border guards in the Republic of India and to conduct comparative analysis with the process of training of personnel of the State Border Guard Service of Ukraine in order to implement creatively some ideas and principles while training border guards in Ukraine.

Key words: professional training, interactive technologies, projects, "pair programming", "flipped classroom", peer learning. 